\title{
LEADERSHIP COMMUNICATION SKILL ON BOARD VESSEL
}

\author{
Vinta Sevilla \\ Universitas Pembangunan Nasional Veteran Jakarta \\ vintasevilla@upnvj.ac.id \\ Ferry Fernando \\ Akademi Maritim Sapta Samudera Padang \\ ferry.fernando25@yahoo.co.id
}

\begin{abstract}
In the maritime world, there are sailors from all over the world who work on a ship. The various cultural backgrounds brought by each crew certainly cannot be denied the same thing. A ship captain must have the ability to lead his ship's crews from various nationalities and cultures. Will be a leader for more responsibility in uniting tasks to carry out the task while on board. Once the complexity of responsibility is inevitable. This paper will discuss how leadership communication skills and a ship captain in command of the crews, interpersonal communication and leadership communication.
\end{abstract}

Keywords: Seaman, Leadership communication, Multicultural communication 


\section{Introduction}

Humans as social beings will never be separated from the activities and processes of communication. Then a variety of questions arise, why do we communicate? And, what is the function of communication for humans? In various perspectives this question will be difficult to answer. If we look from the religious side, we can easily answer that God has given us good communication with reason and language skills. In social life, it has been seen that humans have the ability to communicate to build self-concept and self-actualization.

On the other hand communication means the exchange of symbols between communicants and noncommunicators to exchange information with other humans. This is because humans need other people in their lives. In essence, every day humans live by communicating, both communicating with others and even communicating with themselves or known as intrapersonal communications.

Communication is a process of exchanging thoughts with oral that will not be separated from humans. Humans need communication for their survival. Without communication, humans will not be able to adapt to the environment. Thoman M. Scheidel in Mulyana $(2007,4)$ suggests that we communicate primarily to express and support self-identity, to build social contacts with people around us, and to influence others to feel, think, or behave as we want.

Based on the views of one of the communication experts it is clear that the existence of communication more or less states how we are and how we can influence others around us. Communication becomes the main point in association or social life, by using communication we are able to express what is really in our minds and what is desired. In the context of communication, many things can affect us. One of the points that influence in how we communicate is cultural background.

Its culture forms a person in communication. Starting from the accent, the dialeg, the rhythm and even the arrangement of the language are accidentally formed by culture. As according to Edward T. Hall (1959) in Mulyana and Rachmat (2010, vi) that "culture is communication" and "communication is culture", in the slogan it is clear that between communication and culture are two things that cannot be separated. Cultural differences between two people who are communicating have different value systems, these differences can also be seen from the language, the norms and rules that are followed by the culture.

The above explanation is a view of intercultural communication. Intercultural communication explains that communication is influenced by the cultural values adopted and trusted by someone, then intercultural communication is more informal, personal and not always between nations. Today there is still a misunderstanding in intercultural communication, even though with communication, we are expected to be able to make our desires and goals effective. Someone who associates with other people who have different cultural backgrounds have different views or standards in communicating. 
Very unfortunate, the main problem that arises is that everyone makes their culture the standard of truth and necessity. Though not always what we see right is true before other cultures. This situation does not mean that other people who are communicating with us, we are labeled as a person who is stupid or insensitive, but these conditions are the influence of the culture that they have. This situation makes us so much ethnocentric, that is to draw conclusions about other people based on the limited information we have from that person.

\section{Cross Cultural}

Cross Cultural Communication or cross cultural communication is a process of sending or delivering messages made by certain cultural members to other members of other cultures. Communication like this is related to human behavior and also satisfaction with fulfilling the need to interact with other humans. Crosscultural communication is often intended to mean contained in intercultural communication, without limitation of geographical, racial and ethnic contexts. So, cross-cultural communication is defined as a comparative analysis that prioritizes the relativity of cultural activities. Cross-cultural communication generally focuses on relations between nations without having to form new cultures as they do in intercultural communication.

Meanwhile, according to the Encyclopedia of Communication Theory, Cross cultural is considered as communication that occurs between people from various cultures or people who represent their culture. Cross cultural or cross-cultural communication is distinguished from intracultural communication, which occurs between people sharing a common culture, and intercultural communication, which refers to exchanges in interpersonal settings between individuals from different cultures.

William B. Gudykunst in the Encyclopedia of Communication Theory identifies both intercultural communication and cross cultural culture as intergroup communication segments. More clearly cross cultural occurs when we compare or contrast the communication of people from different cultures and explain how communication varies from one culture to another or compares, "Certain cultural variables and consequences or consequences of cultural influences."

Cross Cultural Communication or cross cultural communication is a process of sending or delivering messages made by certain cultural members to other members of other cultures. Communication like this is related to human behavior and also satisfaction with fulfilling the need to interact with other humans. Crosscultural communication is often intended to mean contained in intercultural communication, without limitation of geographical, racial and ethnic context. Therefore, cross-cultural communication is defined as a comparative analysis that prioritizes the relativity of cultural activities. Cross-cultural communication 
generally focuses on relations between nations without having to form new cultures as they do in intercultural communication.

Cross-cultural communication is also a communication process that compares two cultures or more through cross-cultural surveys. According to Fiber Luce (1991) the nature of cross-cultural studies is a comparative study aimed at comparing:

1. Certain cultural variables

2. Consequences or consequences of cultural influences

Based on these two cultural contexts humans can be expected to be able to understand the culture that they have and also recognize other cultures that others have in intercultural relations.

\section{The Lewis Cross-Cultural Communication model}

Richard Donald Lewis created a cross cultural model called The Lewis Cross Cultural Communication, where this model shows:

a. How people from different cultures have diversity in the concepts of time and space, distance, silence, and eye contact

b. How their style of communication is reflected in the pattern of language they use

c. How they see the truth, as absolute or modified according to the situation

d. How they value world attitudes and views

Lewis divides it into 3 cross-cultural communication cartoons, namely linear-active, multi-active, and reactive. The table below provides an explanation of the three cross cultural types.

Table 1. the Characteristics of Each Cultural Type

\begin{tabular}{|l|l|l|}
\hline LINEAR-ACTIVE & MULTI-ACTIVE & REACTIVE \\
\hline Talks half the time & Talks most of the time & Listens most of the time \\
\hline $\begin{array}{l}\text { Gets data from stats, } \\
\text { research }\end{array}$ & $\begin{array}{l}\text { Solicits information first-hand } \\
\text { from people }\end{array}$ & $\begin{array}{l}\text { Uses both data and } \\
\text { people sources }\end{array}$ \\
\hline Plans ahead step by step & Plans grand outline only & $\begin{array}{l}\text { Looks at general } \\
\text { principles }\end{array}$ \\
\hline Polite but direct & Emotional & Polite and indirect \\
\hline Partly conceals feelings & Displays feelings & Conceals feelings \\
\hline Confronts with logic & Confronts emotionally & Never confronts \\
\hline Dislikes losing face & Has good excuses & Must not lose face \\
\hline
\end{tabular}




\begin{tabular}{|l|l|l|}
\hline Compartmentalizes projects & $\begin{array}{l}\text { Lets one project influence } \\
\text { another }\end{array}$ & Sees the whole picture \\
\hline Rarely interrupts & Often interrupts & Doesn't interrupt \\
\hline Job-oriented & People-oriented & Very people-oriented \\
\hline Sticks to the facts & Juggles the facts & Statements are promises \\
\hline Truth before diplomacy & Flexible truth & Diplomacy over truth \\
\hline Sometimes impatient & Impatient & Patient \\
\hline Limited body language & Unlimited body language & Subtle body language \\
\hline Respects officialdom & Pulls strings & Networks \\
\hline Separates the social \\
professional
\end{tabular}

(Source: The Lewis Cross-Cultural Communication Survey)

We can understand the characteristics of cross cultural communication to realize the nature of communication that each culture has. So that we can anticipate how to get along in different cultures. More specifically, Lewis divides each community according to its communication characteristics.

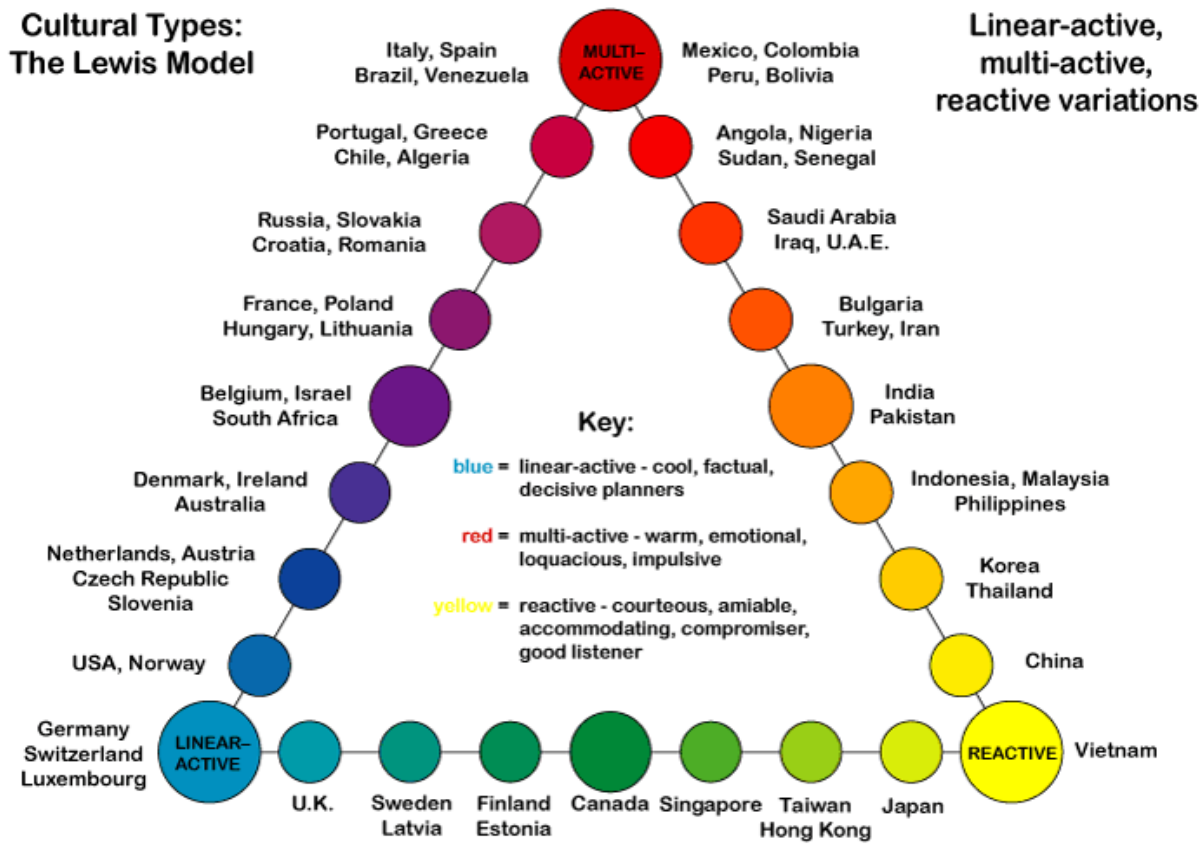

Picture 1. The Lewis Cross-Cultural Communication Model

(Source: The Lewis Cross-Cultural Communication Survey) 


\section{Case Study}

The author discusses the process of intercultural communication experienced by crew members working on foreign vessels. The ship was led by a Dutch captain. In everyday life, English is the main language used by crew members. All crew members work alternately (shift 8 (eight) hours a day), but this does not apply to ship captains who are required to always standby. When picking up, all crew members wear their uniforms, but when the ship is running, ship workers are allowed to wear free clothes. However, when the ship is at the port, it is required to wear a uniform. This is a must to comply with the crew.

The crew was contracted within a few months to suit the needs of the company and the charterers who bound it. During work, the crew adjusted the habits adopted by the captain. In this case, the crew who work with the Dutch captain feels as a "workaholic" person who still has to adjust to being demanded to be active and always responsive.

In communicating, the Captain on this ship will reprimand anyone when making a mistake. They speak directly, but respect the head of each division. This is in line with leadership said to be a process of directing and influencing activities that have to do with the work of group members. Three implications according to Rivai $(2005,84)$ contained in this case, namely: (1) leadership involves other people both subordinates and followers, (2) leadership involves the distribution of power between leaders and group members equally. Because group members are not without power, (3) the ability to use different forms of power to influence the behavior of followers through various means. Whereas Pace and Faules $(2013,276)$ explained that leadership is manifested through work style or how to cooperate with other people who are consistent. Through what he says (language) and what he does (action), someone helps other people to get the desired results.

In addition, in communication, when there is a misunderstanding or other obstacle, other ship workers are immediately willing to help because they have a high awareness of the many differences in terms of language, culture and habits. They really respect that. Referring to the understanding of Ruben and Steward $(1998,16)$ regarding human communication, namely: Human communication, individuals, relationships, groups, organizations and community-responders to and create messages to adapt to the environment and one another. That human communication is a process that involves individuals in a relationship, groups, organizations and communities that respond and create messages to adapt to each other's environment.

Other habits that existed in Japanese people who were inside the ship opposed not to whistle while sailing, they considered this as 'pamali' when sailing. As stated by Hohlet (1978) in Rachmat $(2008,42)$ trust is a cognitive component of sociopsychological factors, trust becomes a belief that something is true or false on the basis of evidence, suggestion of authority, experience or intuition. So trust can be said to be someone's role model for something that happens in its social environment, and is believed by it. In this belief, 
intercultural communication has role models when communicating. He has a standard of how good communication that is not realized is influenced by the culture he believes in.

Due to differences in values and habits, each crew member chooses to respect each other's habits and culture. When there is a misunderstanding, in this situation they will immediately express errors or anomalies to the person concerned, there is no attempt to corner others but respect each other.

Furthermore, when someone who is going to join the room or participate in a group discussion, those who have just come must submit greetings (sentences greetings), with this the people in them feel valued, but not necessarily habits like this can be brought to other foreign ships, can this habit be considered strange by these people.

Another obstacle that often occurs between ship crews is the difficulty of understanding the language, or the presence of ship crews who do not really understand the use of English in their daily lives. But this can still be overcome with the body language that seems to be a helper for their fellow communicators. The natural relationship between language-as-a-symbol (language-as-a-symbols) and values has become an interesting subject to debate. Some researchers claim that language influences values, and other researchers suggest that cultural values determine the form of language. It is possible that this relationship is bidirectional. For example, cultural values might motivate the formation of words that might not be found in other cultures. At the same time, language may be a source of values that are literally "unthinkable" in other cultures because there are gaps in the right terms to discuss them.

Another thing that often happens besides the language barrier is the belief that is held by the ship's crew. When joining a boat crew from India, he did not eat beef at all. In this case, the chef must understand well what is the trust of each crew, and be able to find other alternatives to serve. It is no exaggeration if differences in cultural value orientation can also lead to misunderstandings, and respect for others. This is based on culture and human beings who cannot be separated.

\section{Conclusion}

The complexity of communication is based on the fact that human communication is very diverse which is influenced by the person, environment, and culture that raises it. The life of cross cultural communication in foreign ships is not as complicated as imagined because human beings from various countries cooperate in achieving the goals led by the captain as the leader. Organizational leaders always create good relationships with members, and vice versa. Communication between leaders and members in creating a good relationship within the organization is by using interpersonal communication and mutual respect for the culture that raises it. 


\section{References}

Encyclopedia of Communication Theory. Cross-Cultural Communication. Sage Publication.

Luna, D. dan Gupta, S.F. 2001. An integrative framework for cross-cultural consumer behavior. International Marketing Review, Vol. 18, No. 1, pp. 45-69

Lewis, Richard Donald. 2014. The Lewis Cross Cultural Communication Model.

Mulyana, Deddy. 2007. Ilmu Komunikasi: Suatu Pengantar. Bandung: Remaja Rosdakarya

Pace, R. Wayne dan Don F. Faules. 2013. Komunikasi Organisasi: Strategi Meningkatkan Kinerja Perusahaan. Bandung: Remaja Rosdakarya

Rakhmat, Jalaluddin. 2008. Psikologi Komunikasi. Bandung: Remaja Rosdakarya

Rivai, Veithzal \& Basri, Ahmad, 2005. Performance Appraisal Sistem Yang Tepat Untuk Menilai Kinerja Karyawan dan Meningkatkan Daya Saing Perusahaan. Jakarta: Raja Grafindo Persada

Ruben, Brent, D. dan Lea P. Stewart, 1998. Communication and Human Behavior. USA Viacom Company. 